\title{
Observations and transport modeling of dust storm event over Northeast Asia using HYSPLIT: case study
}

\author{
Gantuya Ganbat $^{1 *}$ and Dulam Jugder ${ }^{1}$ \\ ${ }^{1}$ Information and Research Institute of Meteorology, Hydrology and Environment, Juulchiny street - 5, BagaToiruu-3, \\ Ulaanbaatar 15160, Mongolia
}

\begin{abstract}
This study analyzes a regional dust storm event that occurred in spring 2016 using data from observation sites, Lidar measurements, and satellite imageries. $\mathrm{PM}_{10}$ concentrations at surface observation stations are considered as a primary indicator of the dust events. The dust events occurred on 3-12 March with $\mathrm{PM}_{10}$ reaching a maximum beyond $1682,1498,706$, and $165 \mu \mathrm{g} \mathrm{m} \mathrm{m}^{-3}$ at observation sites in Mongolia, China, Korea and Japan, respectively. The dust event in Northeast Asia is captured by time series of $\mathrm{PM}_{10}$ concentrations at observation sites. On 3-4 March, the dust storm event originated from Mongolia move toward China, Korea and Japan. Vertical distributions of dust observed by Lidar measurements from stations in AD-Net capture a thick layer of nearly $2.2 \mathrm{~km}$ of high concentrations above surface in the area of origin. The maximum $\mathrm{PM}_{10}$ concentration drops with downwind transport. Dust source identification and dust-loaded air parcel trajectories are calculated using the HYSPLIT model. According to the HYSPLIT model, the dust storm started on 3-4 March from Mongolia and reached northern Japan in about 4 days passing over northern China and Korea.
\end{abstract}

\section{Introduction}

Dust storms in Northeast Asia from the Gobi deserts $[1,2]$ and northern China and western China. Frequent cyclonic activities over Mongolia result in frequent dust storms in Northeast Asia specifically during springtime [3]. Dust storms usually occur in high shear wind speed and low moisture in air and soil, and 70\% of dust storms occur in dry soil conditions in Mongolia [3]. Statistical study on the dust storms observed in Mongolia showed that the number of dusty days varies with period of time.

Asian dust can spread out in wide areas and studies showed that the Gobi Desert is the origin of southwestward transport of Asian dust [4]. Statistical study has demonstrated that the dust-loaded air parcels are further transported eastward and southeastward forming regional dust storm events and the dust raised from the Gobi deserts is likely to be entrained to a height of $<3 \mathrm{~km}$ [5]. It was shown that about $400 \mathrm{Tg}$ of Asian dust are transported over long distances downwind of source regions by westerly winds [6]. A modeling approach demonstrates that the dust originated from the Mongolian Gobi has the potential to travel to the far Pacific, North America [7], and even to Arctic [8] under favorable weather conditions.

\footnotetext{
*Corresponding author: gantuyaG@gmail.com
}

Different techniques (such as surface dust observations, remote sensing, satellite imagery, numerical modeling, trajectory analysis etc.) have been widely applied to investigate the dust storm events. To estimate the origins and trajectories of dust aerosols, the Lagrangian models are widely used. The HYSPLIT model has been applied in prior studies to examine the source of dust events [9, 10].

This study analyzes dust event in Northeast Asia region that occurred in 2016 using surface dust observations, satellite imageries and numerical modeling. Here, we report a case study of Northeastern Asian dust event on 3-12 March is reported here.

\section{Data and methods}

Several datasets are used in this study to assess the dust events in northeast Asia during spring 2016. Hourly $\mathrm{PM}_{10}$ concentrations measured at surface observation sites in Mongolia (4 sites operated by National Agency for Meteorology and Environmental Monitoring, NAMEM), China (10 sites operated by China National Environmental Monitoring Center), Korea (20 sites operated by Korea Meteorological Administration), and Japan (10 sites operated by the Ministry of the 
Environment, Japan) are used. Weather maps and records of meteorological stations obtained from the NAMEM are analyzed.

In addition to the ground measurements, lidar measurements from stations in AD-Net, the Asian dust and aerosol lidar observation network [11], are used to observe the vertical distribution of dust. The trajectory of an air parcel containing dust which arrives at the final destination is traced back for several days.

In order to analyze the origins and trajectories of horizontal and vertical pathways of dust aerosols, HYSPLIT (Hybrid Single Particle Lagrangian Integrated Trajectory) model has been utilized with $0.5^{\circ} \times 0.5^{\circ}$ resolution meteorological data. HYSPLIT model is capable in computing both simple air parcel trajectories and complex dispersion and deposition simulations. Three types (normal, matrix, and ensemble) of trajectories can be computed by HYSPLIT. The space and time calculations of path of individual air parcel can be done by the matrix trajectory calculation. More details can be found at http://www.ready.noaa.gov/HYSPLIT.php (NOAA Air Resources Laboratory).

\section{Results}

Both surface and satellite observations/retrievals are used to identify dust events. As indicator of dust, $\mathrm{PM}_{10}$ concentrations are considered. Table 1 shows the maximum of hourly $\mathrm{PM}_{10}$ concentrations at observation sites in Mongolia, China, Korea and Japan for the period 3-8 March. Time series of $\mathrm{PM}_{10}$ concentrations at observation sites capture the dust event in northeast Asia. Enhanced $\mathrm{PM}_{10}$ concentration of $1682 \mu \mathrm{g} \mathrm{m}^{-3}$ is observed at the Dalanzadgad station, Mongolia, on 4 March when the dust event is originated over the Mongolian Gobi. On the same day, the maximum hourly $\mathrm{PM}_{10}$ concentration reaches $1498 \mu \mathrm{g} \mathrm{m}^{-3}$ at Hohhot station, China, confirming the arrival of the dust event. Further, two days later, the $\mathrm{PM}_{10}$ concentrations decrease rapidly to about $700 \mu \mathrm{g} \mathrm{m}^{-3}$ in western Korea. Later, the maximum $\mathrm{PM}_{10}$ concentration reaches $165 \mu \mathrm{g} \mathrm{m}^{-3}$ in northeastern Japan. The dust has accounted for approximately 90 , 47 , and $23 \%$ of observed $\mathrm{PM}_{10}$ concentrations at stations in China, Korea, and Japan, respectively, during southeastward transport of dust event on 3-12 March.

Table 1. Maximum $\mathrm{PM}_{10}$ concentration at observation sites in Mongolia, China, Korea, and Japan.

\begin{tabular}{|c|c|c|c|}
\hline $\begin{array}{l}\vec{E} \\
\dot{E}\end{array}$ & Site & $\begin{array}{c}\text { Max. } \\
\text { PM }_{10}, \\
\mu \mathrm{g} \\
\mathbf{m}^{-3}\end{array}$ & Max.Period \\
\hline \multirow{4}{*}{ 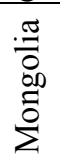 } & Dalanzadgad & 1682 & $4 \mathrm{Mar}$ \\
\hline & Sainshand & 350 & $4 \mathrm{Mar}$ \\
\hline & Zamiin-Uud & 472 & $4 \mathrm{Mar}$ \\
\hline & Ulaanbaatar & 135 & $5 \mathrm{Mar}$ \\
\hline 0 : & Baotou & 1335 & $4 \mathrm{Mar}$ \\
\hline
\end{tabular}

\begin{tabular}{|c|c|c|c|}
\hline & Chifeng & 718 & $5 \mathrm{Mar}$ \\
\hline & Hohhot & 1498 & 4 Mar \\
\hline & Yan'an & 1308 & 4 Mar \\
\hline & Datong & 680 & 4 Mar \\
\hline & Dalian & 287 & $6 \mathrm{Mar}$ \\
\hline & Ji'nan & 491 & 5 Mar \\
\hline & Jinzhou & 341 & 4 Mar \\
\hline & Shenyang & 798 & $5 \mathrm{Mar}$ \\
\hline & Qingdao & 324 & 6 Mar \\
\hline \multirow{19}{*}{$\begin{array}{l}\tilde{D} \\
\stackrel{0}{0} \\
\ddot{V}\end{array}$} & Sokcho & 114 & $8 \mathrm{Mar}$ \\
\hline & Gwangde & 166 & 6 Mar \\
\hline & Deagwallyeong & 86 & 8 Mar \\
\hline & Baengnyeongdo & 706 & 6 Mar \\
\hline & Ulleungdong & 78 & $8 \mathrm{Mar}$ \\
\hline & Kwanaksa & 160 & 6 Mar \\
\hline & Yeongwol & 82 & 8 Mar \\
\hline & Kwago & 238 & $6 \mathrm{Mar}$ \\
\hline & Andong & 114 & 8 Mar \\
\hline & Gunsan & 166 & $6 \mathrm{Mar}$ \\
\hline & Daegu & 109 & $8 \mathrm{Mar}$ \\
\hline & Gwangju & 117 & $8 \mathrm{Mar}$ \\
\hline & Gudeoksan & 104 & $8 \mathrm{Mar}$ \\
\hline & Heuksando & 305 & $6 \mathrm{Mar}$ \\
\hline & Gosan & 94 & $8 \mathrm{Mar}$ \\
\hline & Jinju & 96 & 6 Mar \\
\hline & Ganghwa & 190 & $6 \mathrm{Mar}$ \\
\hline & Cheonan & 156 & $6 \mathrm{Mar}$ \\
\hline & Uljun & 92 & $8 \mathrm{Mar}$ \\
\hline \multirow{9}{*}{ 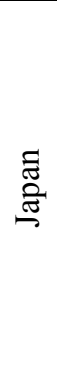 } & Rishiri & 160 & $7 \mathrm{Mar}$ \\
\hline & Ochiishi & 165 & $8 \mathrm{Mar}$ \\
\hline & Tappi & 58 & $8 \mathrm{Mar}$ \\
\hline & Sado-seki & 71 & 3 Mar \\
\hline & Ijira & 72 & $8 \mathrm{Mar}$ \\
\hline & Oki & 79 & 8 Mar \\
\hline & Banryu & 100 & $8 \mathrm{Mar}$ \\
\hline & Yusuhara & 88 & $8 \mathrm{Mar}$ \\
\hline & Ogasawara & 53 & $6 \mathrm{Mar}$ \\
\hline
\end{tabular}

As one of the indicators of a dust event, the extinction coefficients by lidar measurement for March 2016 at several stations in Mongolia, Korea, and Japan, are shown in Figure 1. The stations belong to the ADNet [11]. According to the vertical distribution of dust, the measurement of extinction coefficient demonstrates that, on 3-4 March, the dusts are observed in a thick layer up to $2.2 \mathrm{~km}$ near the area of origin (Sainshand site, Mongolia), and further the dust travels to Japan passing by the north of Korean Peninsula as compared to the area of its origin. An elevated dust layer is observed at around $0.7-3.0 \mathrm{~km}$ at the Takikawa site in the early hours on 8 March. Further, at the later hours, the dust layer is observed from near the ground up to $<1 \mathrm{~km}$. Thus these trajectory pathways are responsible for relatively lower $\mathrm{PM}_{10}$ concentrations at some sites which are located in southern part of Korea (Table 1). The high concentrations at southern site of Korea (Jeju) are not obvious. 

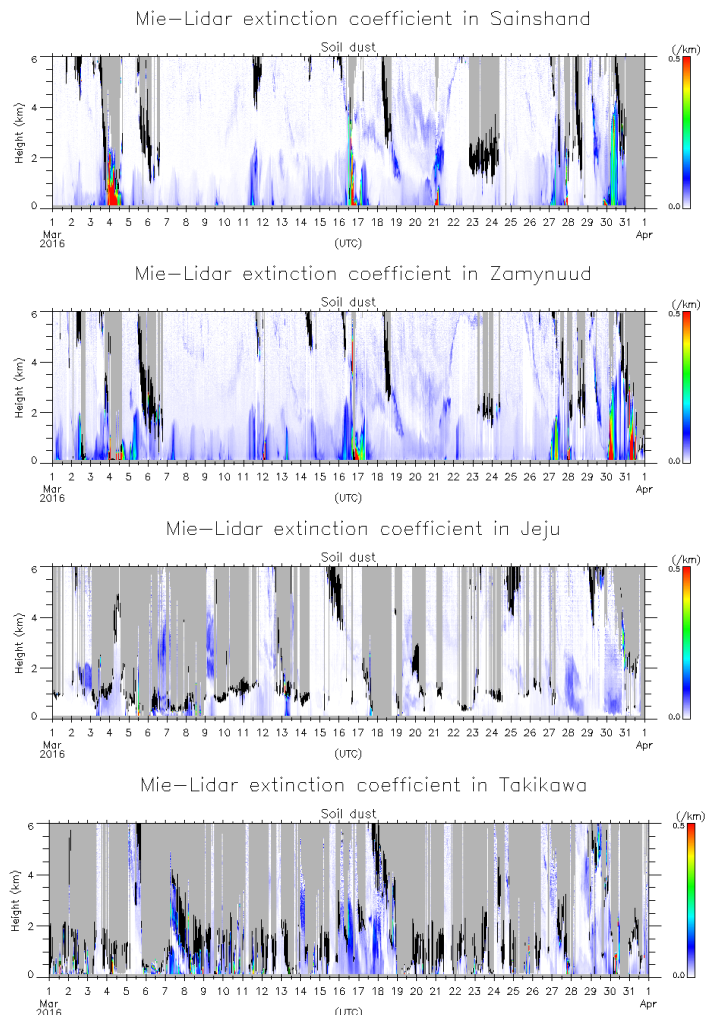

Fig. 1. Mie-Lidar dust extinction coefficient showing vertical distribution of soil dust 2-12 March 2016 at Sainshand, Zamynuud, Jeju and Takikawa.

To further examine the transport of Asian dust, the ensemble HYSPLIT backward trajectory model is applied to identify the source area of the dust event. The back-trajectories of the dust event are shown in Figure 2. Figure 2 indicates that the dust-loaded air parcels are transported from Mongolia to the northeastern Japan. The particle backward trajectories are calculated for $96 \mathrm{~h}$ periods starting from $10 \mathrm{~m}$ above the receptor sites. The dust-loaded air parcels arriving in northeastern Japan at 23 UTC on 7 March are originated from Mongolia and pass over north China and Korea. The passage duration from Mongolia to Japan is nearly 4-5 days which is in agreement with measurements of surface $\mathrm{PM}_{10}$ concentrations. Height of dust transport passages varies with time.

\section{Summary}

In the present study, the dust event that occurred over Northeast Asia on 3-12 March 2016 is analyzed using surface observation data, satellite imageries, and numerical modeling. As the nature of dust events may not be exactly the same for each event, the dust storm event on 3-12 March is documented in this short paper and the analysis of the other events will be given on the conference talk. As a primary indicator of the dust events, $\mathrm{PM}_{10}$ concentrations monitored at surface stations are analyzed. The dust events are captured by the time series of $\mathrm{PM}_{10}$ concentrations at observation sites, vertical measurements at Lidar network stations. Surface dust observations show that the maximum

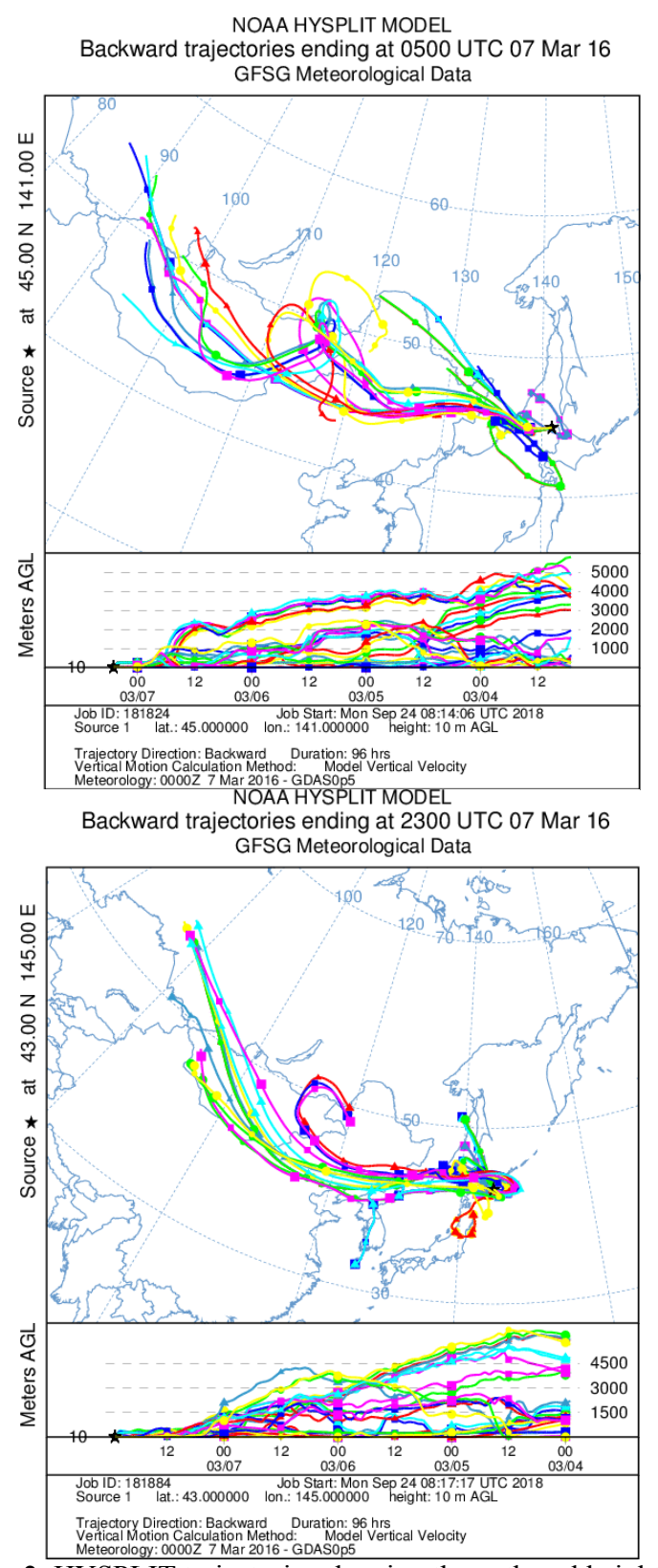

Fig. 2. HYSPLIT trajectories showing the path and height of the dust-loaded air parcel arriving Rishiri and Ochiisi, Japan, originate from Mongolia. Colors indicate the individual air parcels arriving from different source areas.

$\mathrm{PM}_{10}$ concentration varies from 1682 to $165 \mu \mathrm{g} \mathrm{m}^{-3}$ during 3-12 March with a time lag from Mongolia to Japan. Measurements at Lidar stations showed thick layer of dust in the Mongolian Gobi, which is an origin area of dust, and further the layer descends at distant sites. Trajectory calculations by HYSPLIT verify the origin of dust-loaded air parcel and its transport pathway. Analysis shows that the Asian dust over Northeastern Asia can last for several days and the dust concentrations drop and the layer with dust-loaded air parcel descends with dust travels downwind.

We appreciate the insightful comments of the two anonymous referees. Thanks to Dr. Atsushi Shimizu for valuable suggestions. The lidar data were obtained from http://www-lidar.nies.go.jp/. 


\section{References}

1. L. Natsagdorj, D. Jugder, Y.S. Chung, J. Kor. Met. Soc 38, 209-223 (2002)

2. D. Jugder, Y.S. Chung, A. Batbold, J. Kor. Met. Soc 40, 293-303 (2004)

3. L. Natsagdorj, D. Jugder, Y.S. Chung, Atm. Env 37, 1401-1411 (2003)

4. S.-C. Hsu, S.C. Liu, Y.-T. Huang, S.-C.C. Lung, F. Tsai, J.-Y. Tu, S.-J. Kao, J. Geo. Res 113, D18306 (2008)

5. J. Sun, M. Zhang, T. Liu, J. Geo. Res 106, 325-333 (2001)

6. X.Y. Zhang, R. Arimoto, Zh.S. An, J. Geo. Res 102, 28041-28047 (1997)

7. J. Guo, M. Lou, Y. Miao, Y. Wang, Zh. Zeng, H. Liu, J. He, H. Xu, F. Wang, M. Min, P. Zhai, Env. Poll 230, 1030-1039 (2017)

8. Zh. Huang, J. Huang, T. Hayasaka, Sh. Wang, T. Zhou, H. Jin, Env. Res. Let 10, 114018 (2015)

9. Y.C. Lee, X. Yang, M. Wenig, Atm. Env 44, 3728-3738 (2010)

10. T. Logan, B. Xi, X. Dong, R. Obrecht, Z. Li, M. Cribb, J. Geo. Res 115, D00K25 (2010)

11. A. Shimizu, T. Nishizawa, Y. Jin, S.-W. Kim, Z. Wang, D. Batdorj, N. Sugimoto, Opt. Eng 56, 031219 (2017) 